\title{
A tidal power environmental impact assessment : case study of the Kislogubskaija experimental tidal power station (Russia)
}

\author{
par N.N. Marfenin, O.I. Malutin, A.N. Paniulin, N.M. Pertzova
}

Moscow State University

\section{INTRODLCTION}

The experimental Kislogubskaija Tidal Power Station (KTPS) was constrteted in Russia near Murmansk at the bay of Kislajat in 1963-68 (fig. 1). The tidal amplitude here is up to $4 \mathrm{~m}$, with maximum stream velocity up to $3,6 \mathrm{~m} / \mathrm{sec}$. KTPS has one turbine of $400 \mathrm{~kW}$ capacity, and one near-bottom floodgatc. Kislaija Guha is a long $(3.3 \mathrm{~km})$ and narrow bay, whose general surface is 1.1 sq.km with a narow opening $65 \mathrm{~m}$ wide and $10 \mathrm{~m}$ decp. The bottom of the bay has two hotlows, bott $35 \mathrm{~m}$ dcep, with a high threshold up to $4 \mathrm{n}$ ? deep between them. A freshwater stream empties into the bay from the nearest lake.
Previous investigations of the Kislaija Gubil were done in the 1920s, and in 1964. Those researches were different one from wnother by methods, firal goals, and studiced areas. The investigation of the $1920 \mathrm{~s}$ was a part of the first pinot exploration of the Burents Sca shallow water marine fauna.

Second faunstic description has been made in 5964 for the special purpose of scientific prediction of possible marine fouling risk for the future tidal power building anderwater part and hydroaggegate. Therefore both funnistic lists are differed sigenifteantly, including only $1 / 4$ commort species. After the construction of KTPS it was studied episodically.

Impact environnemental de la production marémotrice d'électricité : étude de cas sur la centrale expérimentale de la baie de Kislaija

La centrale marémotrice expérimentale Kislogubskaija a été construite en Russie près de Mourmansk dans la baie de Kistaija entye 1963 et 1968 . La production démarrée en 1974 était discontinue. L'échathge d'eau entre la baie et la mer a été beaucoup réduit. En conséquence, les 15 mètres supérieturs de la conche deau sont devenus moins salés et les 20 mètres en dessous contenaient de l'hydrogène sulfurế. L'écosystème marin nomal a été complètement détriit.

A partir de 1984, les échanges d'euu avec la mer ont augmenté de 30 d̀ $40 \%$. la centrale ayant atteint son régine de croistẹre. Les écosystèmes ont été restaurés lentement, le plancton plus vite gue la faune benthique. Actuellement, on obsenve peu de différences avec la population antérieure Le nombre d'espèces de polychaetes a même atigmenté:

Le cas de l'usine KTP illustre le plus important impact qu'une usine marémotrice puisse avoir sur les écosystèmes marins. On suppose que suy des sites plus êtendus, linpact serait noins important. 


\section{D RESULTS AND DISCLSSION}

Beginning in 1974, KTPS produced electricity discontinuously. Water exchange between the bay and the open sea declined drasticatiy (fig. 2). As al result, the upper $15 \mathrm{~m}$ layer of water was less stline, and the deper $20 \mathrm{~m}$ of water conterined hybrogen sulphide.

The negative ecological effect born by some problems of KTPS exploitation became much stronger becatse of the unique topograpiny of the Bay: long lorm, ramow and shatlow opening, and high threstrotd, dividing the bottom zone on two decp holes one after another. The norma: marine ecosystcm was destroyed significantly.

A complex oceanolorical study of the KTPS cnvirommen[ial impact begar in 1983 under leadership of Dr. V.N. Semenov $1 \mathrm{f}$ f from the Murmansk Marine Biological Institute. From 1990 up to now the investigations were continued by scientists from tine Moscow State University heaced by Prof N.N. Varfenin $[2,3,4,5]$.

The expedition of 1983 described the complete absence of athe animats below $20 \mathrm{~m}$ in the hydrogen sulphide zone, and some obvious signs that the life has been there before the disister. There was found significant decline of the marine invertebrates abundance above $20 \mathrm{~m}$ deep in the shelly water rone. The association of the algae bele on littotal zone vanished together with atgate itself.

Nevertheless the general fauna list has been rich enough including 92 species of the zoobenthos (frg. 3)

Beginning in 1984 the water exchange of the Kislaija Guba with the open set increased up $1030-40 \%$ of the naturai one, which conesponded to project regime.

As a result in 1992 it was possible to recognize four water layers in Kislaja Guba differed by temperature and salinity parameters ffig. 4). The surface layer is a less stabile water body, which is timely significally freshed by terrestrial flow. The subsurface layer tukes the outside water, coming during a water exchange through the near-bottom floodgate. The decp water layer is more stable because of the low vertical convection during the stmmer season.

As a result the marine ecosystems began slowly to be restored. The plankton community in the KTPS basin developed according to the norm better than the bentios. Alteady in 1991-92 we did not find considerable dificrences in specics composition and the age structure of inner and outer communities. Nevertheless rooplankton abundance in the upper $10 \mathrm{~m}$ water laycr of the inner community continued to bc about a half of the outer one (fig. 5).

The berthic ecosystems of the KTPS basin are slowly comirg according to the norm. From 1983, the biomass and quantity of benthic invertebrates increased significantly.

They even recolonized the nearest hollow to the KTPS, where no hydrogen sulphide contanination is registered now.

The macrophytes belt is slowly regrowing around a rocky fittoral zonc, crcating a biotope for the sedentary invertebratcs such as sponges, hydroids, and bryozoans, which had vanished from Kistaija Baty after the disaster

Benthos species diversity of the Kistaja Guba changed significantly since 1983. In 1992 we found 140 species of macrofuma from 52 sample plots ffig. 3) (compare with 91 species in 1983), athough we use for collection only the small Petersen grab (0.04 sq.m) without squbal diving methods.

37 benthos specics proved to be highty resistant to the dramatic changes of the water environment (fig. 6). 11 species most probably vanished after the calastrophic environment change in the bay. 6 of them did not collected since 1983, and 5 more did not registered in 1992 (fig. 7).

There is no dount that the list of the vanished benthos species should be much longer including small groups, which are registered occasionally. 151 species have been

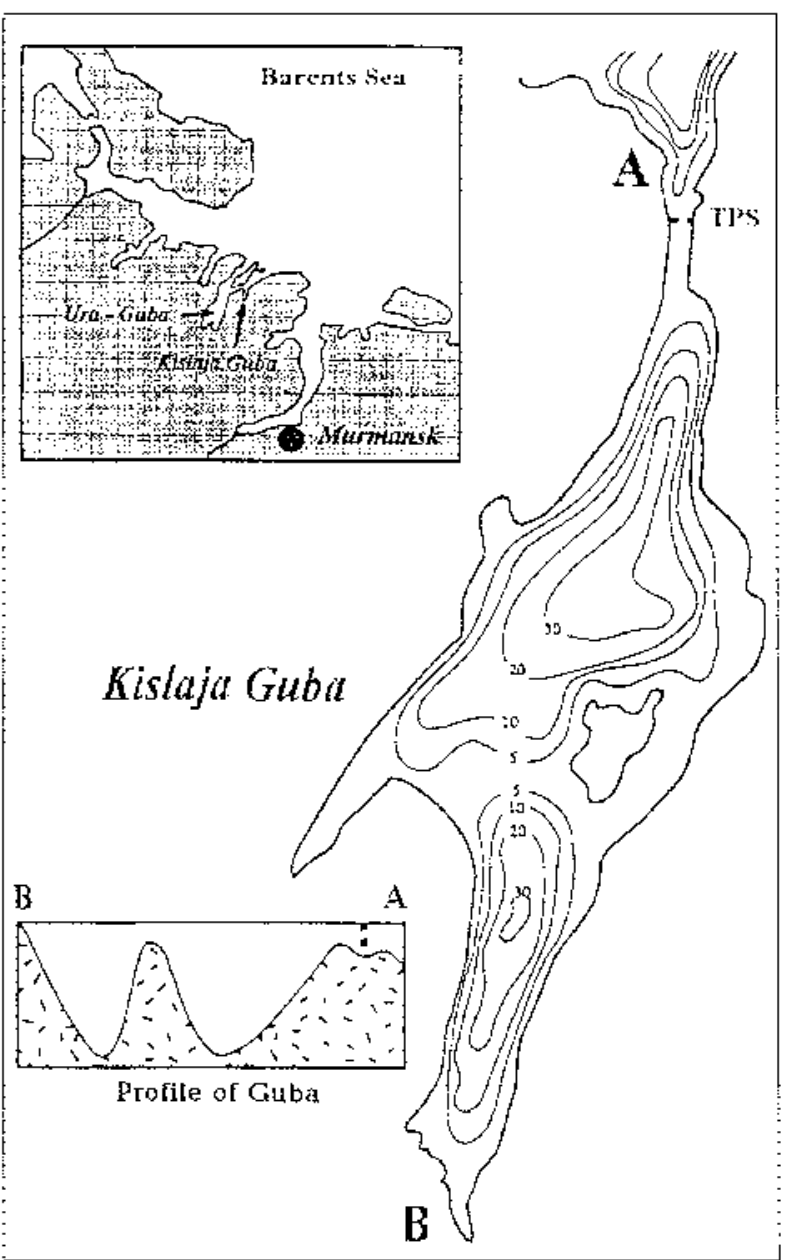

1. Disposition of KTS on the coast of the Barents Sea.

described by 2 expeditions (1924 and 1964) before TPS construction, and 75 species from them were found only once. Approximately the same proportion of the rare spccies were tr $1983(26 \%)$ and $1992(48 \%)$.

18 common species have absented in fauna list of 1983 , have been then anew discovered in 1992 (fig. 8). Following the graduat change of the biotope parameters numerous new species took root in the Kistaja Guba benthos ecosystem. 17 new species were found in 1983 and following expeditions ffig. 9\%. More new species have been registered in 1992

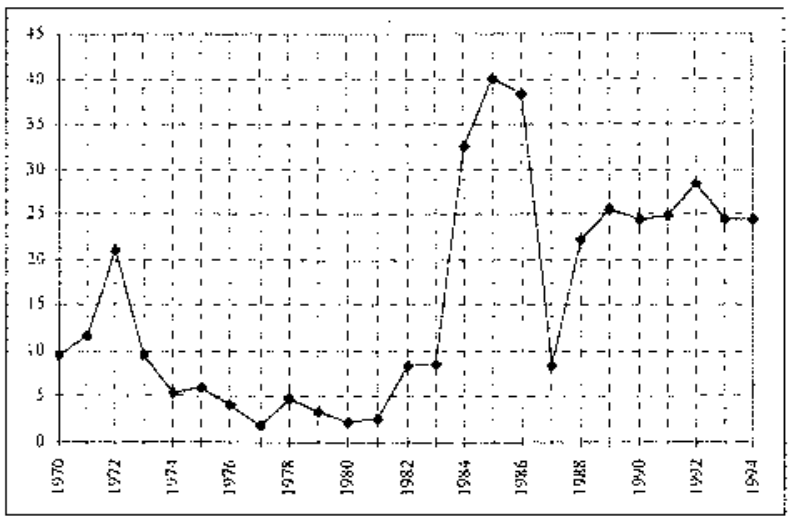

2. Water exchange reduction between the Kislaja Guba and Ura-Guba (data by I.N. Lsachev). 


\begin{tabular}{|c|c|c|c|c|c|}
\hline & 1924 & 1964 & 1983 & 1992 & $\begin{array}{c}\text { All expeditions } \\
\text { together }\end{array}$ \\
\hline $\begin{array}{l}\text { Spongia } \\
\text { Hydrozoa } \\
\text { Actiniaria } \\
\text { Turbellaria } \\
\text { Nemertini } \\
\text { Polychaeta } \\
\text { Priaputidae } \\
\text { Sipunculidae } \\
\text { Loricata } \\
\text { Gastropoda } \\
\text { Bivalvia } \\
\text { Cirripedia } \\
\text { isopoda } \\
\text { Cumacea } \\
\text { Amphipoda } \\
\text { Decapoda } \\
\text { Acarina } \\
\text { Bryozoa } \\
\text { Echinodermata } \\
\text { Ascidia. }\end{array}$ & $\begin{array}{c}2 \\
3 \\
1 \\
1 \\
3 \\
29 \\
2 \\
1 \\
2 \\
16 \\
9 \\
2 \\
- \\
3 \\
5 \\
3 \\
2 \\
4 \\
4\end{array}$ & $\begin{array}{l}4 \\
5 \\
2 \\
- \\
21 \\
- \\
- \\
\overline{18} \\
11 \\
4 \\
\frac{2}{1} \\
3 \\
20 \\
7 \\
2\end{array}$ & $\begin{array}{l}- \\
\overline{2} \\
\overline{-} \\
32 \\
\overline{-} \\
3 \\
16 \\
21 \\
3 \\
- \\
2 \\
3 \\
- \\
9 \\
3\end{array}$ & $\begin{array}{c}+ \\
1 \\
\frac{1}{+} \\
+ \\
66 \\
1 \\
2 \\
2 \\
15 \\
19 \\
2 \\
4 \\
15 \\
4 \\
2 \\
6 \\
>1\end{array}$ & $\begin{array}{c}>6 \\
6 \\
3 \\
1 \\
3 \\
89 \\
2 \\
2 \\
4 \\
39 \\
27 \\
4 \\
2 \\
4 \\
19 \\
9 \\
3 \\
22 \\
13 \\
4\end{array}$ \\
\hline & 92 & 100 & 94 & 140 & 262 \\
\hline
\end{tabular}

3. The number of invertebrate species in Kislaja Bay described by expeditions in 1924, 1964, 1983, 1992 separately, and the faunistic list according to atl expeditions together.

Now the number of polychaetes species (which is 66 ) is about double the previousty known number before the creating of the KTPS and after the dramatic deformation of the ecosystems in the late 70 -s

Gastropoda and Amphipoda fauna changed significantly. Although the total number of Gastropoda species varied little in comparing the data, the shallow water species which once dominated the fauna, are now characterized by low abundance.

Remarkable fact is the absence of Isopoda group in last collecting and atmost completely declining of the Bryzosn species number, and on the contrary finding in 1992 Cum:cea group species from Crustacia.

If the abiotic crvironment continues to be stable in the future, we ma expect stosequent development of the benthos commutity.
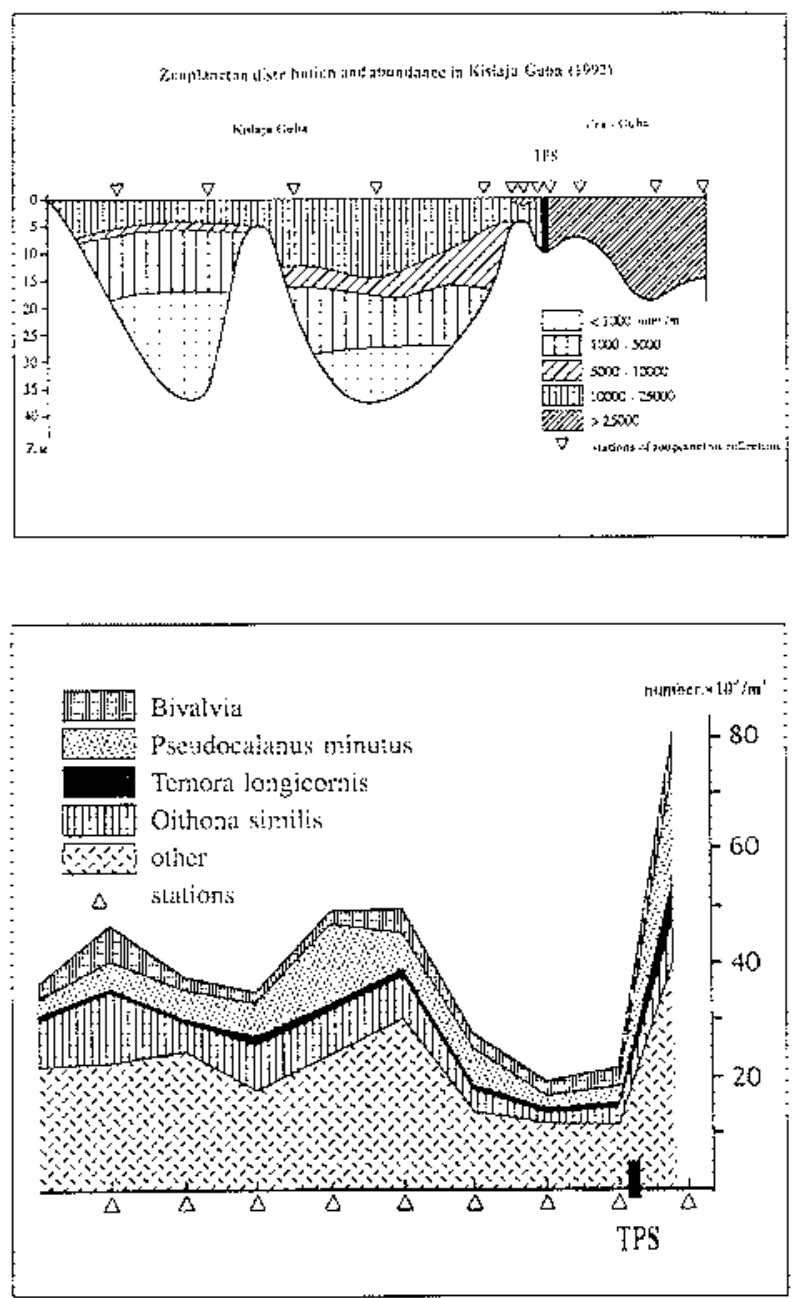

5. Zooplacton distribution and abundance in the Kislaja Guba :

the top picture - total number of zooplancters along the longitudinal section of the bay;

the bottom picture - numbers of the dominant zooplancters in upper $10 \mathrm{~m}$ water layer same section of the bay.

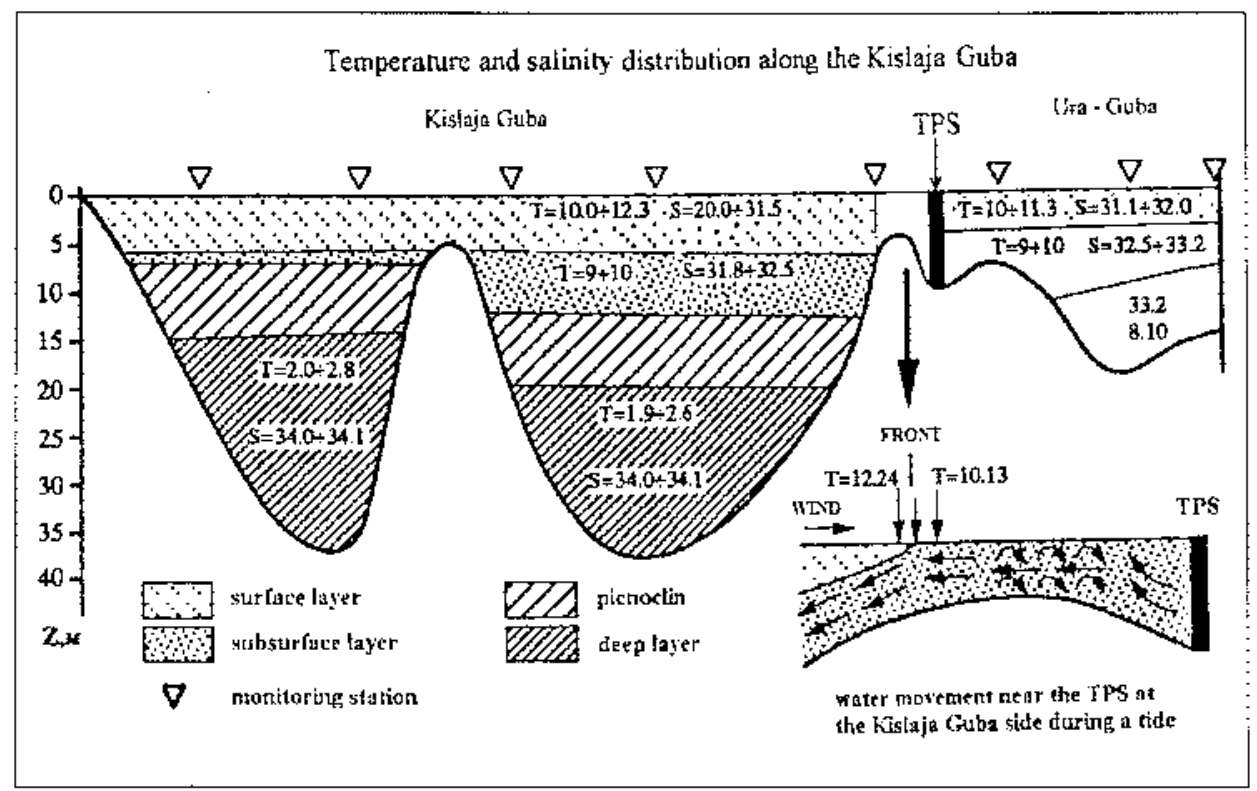

4. Temperature and salinity distribution along the Kislaja Guba. 
Nevertheless its structure should be different fron tho intiat one. There are several main reasons for the ecosystem changes which stijl exist, stech as a signitietrltecrease of the water exchange, which has produced a deformation of the basin hydrography stucture and the near-botton water dymanic.

Developing ecosystems have to be adapted to a new environmental situation. This adtptation is reflected in a changed species structure and changed trophical characterislies of the dominants. Thus the ecosystems of Kislajja Buty underwent a dramatic collapse after 8 years of the KTPS mismandye, but since ther we have found a trend of recolonization of the bay and improvement of heavily destroyed communitics.

This progress has happened in a situation extremely unfavorable for tite pelagic and benthic commuritics inhabiting the aquatorium of this tidal power station, due to atypicat configutation of Kislajja bay coate, a narrow and shallow opening, two deep hollows in the basitn, and very low water exchange between the bay and the open sea.

The Kisleija Guba case study helps us to expose the most stronis impact of TPS on marine ecosystems, which probably could be avoided on big tidal power stations.

We suggest that the environmental impact of typical TPS would not tincaten biological diversily and productivity of isolated marine ecosystems as much as we observed on KTPS during the present study.

\begin{tabular}{|lccccc|}
\hline Lost before 1983 & 1924 & 1964 & 1983 & 1992 \\
\hline Obelia flexuosa & + & + & - & - \\
Oynamena pumilla & + & + & - & - & \\
Fabricia sabella & + & + & - & - \\
Lacuna divaricata & + & + & - & - \\
Littorina palliata & + & + & - & - \\
Flustrellidra hispida & + & + & - & - \\
\hline Lost before 1992 & 1924 & 1964 & 1983 & 1992 \\
\hline Chone unfundibuliformis & + & + & + & - \\
Anomia Heteranomial squamula & + & + & + & - \\
Chiamys islandicus & + & + & + & - \\
Balanus crenatus & + & + & + & - \\
Gammarus locusta & + & + & + & - \\
\hline
\end{tabular}

7. The « vanished" macrozoobenthos species, whose population obviously degradated up to 1983 , or up to 1992.

\begin{tabular}{|c|c|c|c|c|}
\hline Species & 1924 & 1964 & 198 & 992 \\
\hline Littorina saxatilis (1. rudis) & + & $\dot{-}$ & - & 4 \\
\hline Nicania montaqui (A. banksi) & + & + & - & + \\
\hline Hyas araneus & + & $\perp$ & - & + \\
\hline Phyllodoce maculata & + & - & 一 & + \\
\hline Syllis fasciata & + & - & - & + \\
\hline Nephthys coeca & + & - & - & + \\
\hline Flabelligera affinis & - & $\div$ & 一 & + \\
\hline Stylarioides plumosa & 一 & + & - & + \\
\hline Aricidia nolani (A. uschakovi) & + & - & - & + \\
\hline Praxiffela praetermissa & + & - & - & + \\
\hline Terebeltides stroemi & + & - & - & + \\
\hline Priapulus caudatus & + & 一 & - & + \\
\hline Buccinum sp. & 一 & - & - & + \\
\hline Hydrobia ulvae & 一 & + & - & + \\
\hline Phascolosoma eremita & + & - & - & + \\
\hline lehnochiton albus & + & 一 & - & + \\
\hline Scrupocellaria scabra & 一 & + & - & + \\
\hline Chiridota laevis & + & - & - & + \\
\hline
\end{tabular}

8. The " vanished" in 1983 macrozoohenthos species, which recolonized biotope again up to 1992 .

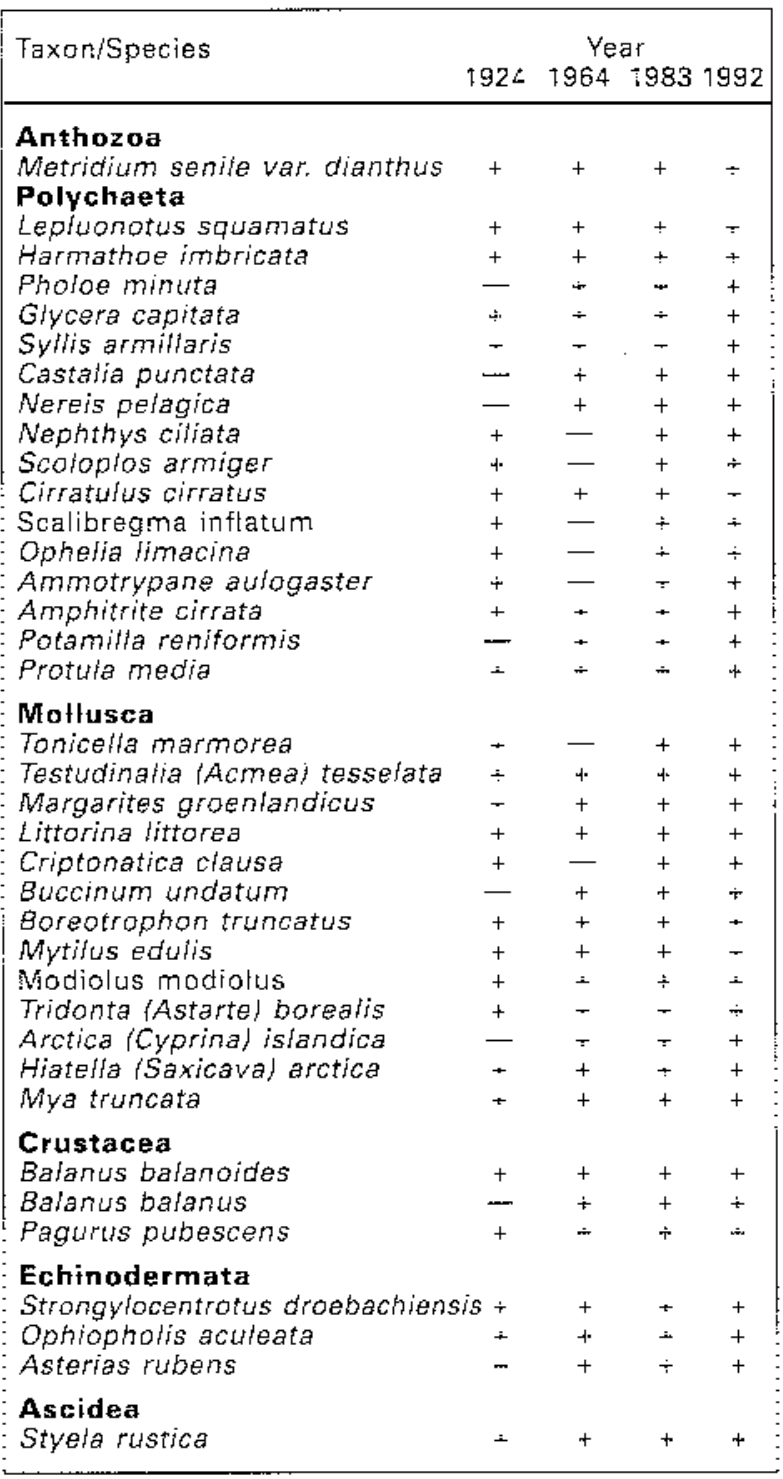

6. List of the " resistent species $»$ of marine macrofauna from the Kistaja Guba, collected both before, and after KTPS construction.

\begin{tabular}{|lllll|}
\hline Species & 1924 & 1964 & 1983 & 1992 \\
\hline Phyllodoce groeniandica & - & - & + & + \\
Lumbrinereis fragilis & - & - & + & + \\
Spiochaetopterus typicus & - & - & + & + \\
Chaetozone setosa & - & - & - & - \\
Praxilleta gracilis & - & - & + & + \\
Pectinaria hyperborea & - & - & + & + \\
Trichobranchus glacialis & - & - & + & + \\
Lepeta coeca & - & - & + & + \\
Cylichna alba & - & - & + & + \\
Leionucula tenuis & - & - & + & + \\
Crenella decussata & - & - & + & + \\
Elliptica elliptica (A. compressa) & - & - & + & + \\
Cerastoderma fasciatum & - & - & + & + \\
Macoma calcarea & - & - & + & + \\
Macoma baltica & - & - & + & + \\
Mya arenaria & - & - & + & - \\
Ophiura robusta & - & - & + & + \\
\hline
\end{tabular}

9. Immigrated into the Kislaja Guba macrozoobenthos species (registrated in the bay beginning 1983). 


\section{LITERATURE}

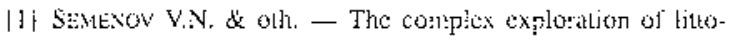
ral and sublittorat ceosystems in the Kistaju Bay for the purpose of es:jiction of the gencral ccological inpact by Kislogubsiana

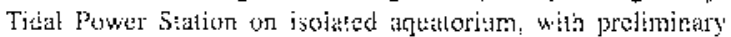
cunshusious abou: pusstble crviromential consegpences afler realisation of plandirg construction and explotittion of the Kolskata TPS. Sci.Report tor the Instiluti Hydroproject, Dat' n:e Zcicnci, MMBl, :984. 74 p. (is: Russiant).

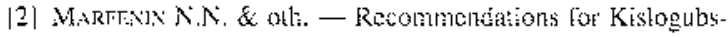

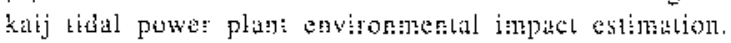

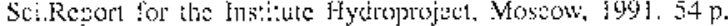
(i:) R:sssiant).

[3] Makman N.N - Fingal discussim and senemizalion join

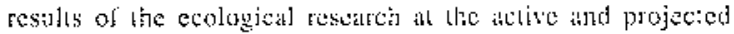
tidal power plant's atglitorials. Sci. Report for the tissiltite Hydroproject, Noscow, !99l. 64 p. (in Russian).

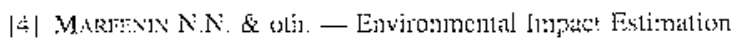
fo: the Tugar Power Pjatht Projest. - Sei.Rofort to: the Ins:ilute Hytronsogect, Moweow 1992. 58 p. (in Ressiar).

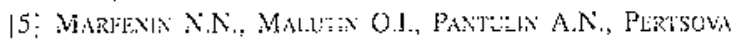

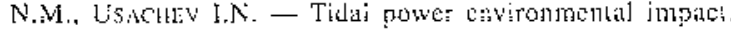
Moscow, Moscow Stite Lzilicrsity, 1995. 125 p. (in Russian). 